\title{
Concentrations of Heavy Metals in Suburban Horticultural Soils and Their Uptake by Artemisia selengensis
}

\author{
CUI Xu ${ }^{1,2,3}$, SUN Xulei ${ }^{1}$, HU Pengjie ${ }^{1}$, YUAN Cheng ${ }^{1}$, LUO Yongming ${ }^{1,4}$, WU Longhua ${ }^{1, *}$ and Peter CHRISTIE ${ }^{1}$ \\ ${ }^{1}$ Key Laboratory of Soil Environment and Pollution Remediation, Institute of Soil Science, Chinese Academy of Sciences, Nanjing \\ 210008 (China) \\ ${ }^{2}$ University of Chinese Academy of Sciences, Beijing 100049 (China) \\ ${ }^{3}$ College of Resources and Environment, Shanxi Agricultural University, Taigu 030801 (China) \\ ${ }^{4}$ Key Laboratory of Coastal Zone Environmental Processes, Yantai Institute of Coastal Zone Research, Chinese Academy of Sciences, \\ Yantai 264003 (China)
}

(Received November 16, 2014; revised May 13, 2015)

\begin{abstract}
A total of 222 surface soil samples and 40 plant samples were collected to investigate the spatial distribution and possible sources of soil heavy metals and to know the uptake and translocation of heavy metals from roots to different plant parts in a representative vegetable production area in the Baguazhou Island, a suburb of Nanjing City, East China. The arithmetic mean values of total Cd, Cr, $\mathrm{Cu}, \mathrm{Ni}, \mathrm{Pb}$, and $\mathrm{Zn}$ concentrations in the soils were $0.314,133,41.0,58.0,31.8$, and $114 \mathrm{mg} \mathrm{kg}^{-1}$, respectively. All of these values were above the topsoil background values in the Nanjing area. Multivariate and geostatistical analyses showed that soil Cd contamination was derived mainly from agricultural practices. In contrast, $\mathrm{Cu}$ and $\mathrm{Zn}$ were derived mainly from soil parent materials and $\mathrm{Pb}$ from atmospheric deposition from highway gasoline stations. Artemisia selengensis, a locally important specialty vegetable, accumulated heavy metals primarily in the edible leaves. The general distribution of heavy metal concentrations in this plant species showed that the highest occurred in the leaves, intermediate in the stems and lowest in the roots. Cd had the highest concentration factor (root-to-soil ratio) and may pose increased health risks in the future to the local population through the consumption of contaminated vegetables. Key Words: concentration factor, plant uptake, pollution source, spatial distribution, translocation factor, vegetable
\end{abstract}

Citation: Cui X, Sun X L, Hu P J, Yuan C, Luo Y M, Wu L H, Christie P. 2015. Concentrations of heavy metals in suburban horticultural soils and their uptake by Artemisia selengensis. Pedosphere. 25(6): 878-887.

Heavy metal pollution may lead to the functional disorder of agricultural and horticultural soils, interfere with crop growth, and may even threaten human health through contamination of the food chain (Lee et al., 2006; Cai et al., 2010; Cai et al., 2012). The main sources of heavy metals may include various anthropogenic activities such as industry, mining, atmospheric deposition, excessive application of chemical fertilizers and pesticides, and sewage and wastewater irrigation (Wilson and Pyatt, 2007; Khan et al., 2008; Wang et al., 2013). Heavy metals can enter plant tissues by uptake from contaminated soils, wastewater irrigation and atmospheric deposition (Huang et al., 2007; Sridhara Chary et al., 2008; Hani and Pazira, 2011; Wang et al., 2013).
Heavy metal pollution of Chinese suburban soils has increased over the last three decades because of rapid industrialization and urbanization (Cheng, 2003; Li et al., 2004; Tan et al., 2006). Commercial and residential vegetable growing areas are often located in the suburbs of the cities and are subject to anthropogenic contamination such as atmospheric deposition, waste disposal, urban effluents, vehicle exhausts, fertilizer application, and long-term application of sewage sludge to agricultural land (Bilos et al., 2001; Hlavay et al., 2001; Koch and Rotard, 2001; Kachenko and Singh, 2006). The application of agrochemicals has increased in Baguazhou Island, a suburb of Nanjing City, East China during the past three decades in order to increase soil fertility. Some of the fertilizers and pesti-

*Corresponding author. E-mail: lhwu@issas.ac.cn. 
cides contain heavy metals such as $\mathrm{Cd}, \mathrm{Hg}, \mathrm{Pb}$, and $\mathrm{Zn}$ and repeated application of these agrochemicals and other soil amendments may have increased the accumulation of heavy metals in the soil. Artemisia selengensis is a perennial herbaceous plant of Compositae and grows near river banks or in swamps, with wild populations widely distributed in Northeast, North and Central China. A. selengensis contains pharmacologically active substances including cineole, artemisia alcohol, and $\beta$-caryophyllene.

The main objectives of this study were to assess the concentrations and distribution patterns of soil heavy metals, to investigate the major sources of heavy metal pollutants, and to know the uptake and translocation of heavy metals from roots to different parts of $A$. selengensis in a representative vegetable production area in the Baguazhou Island of Nanjing City, which will provide a basis for effective targeting of policies to protect soils and consumers from long-term accumulation of heavy metals through the food chain.

\section{MATERIALS AND METHODS}

\section{Study area}

The study area, the Baguazhou Island $\left(32^{\circ} 12^{\prime} 4.6^{\prime \prime}\right.$ $\mathrm{N}, 118^{\circ} 50^{\prime} 112.3^{\prime \prime} \mathrm{E}$ ), was located in the northeast of Nanjing City, Jiangsu Province, East China (Fig. 1). The topography of Baguazhou Island is flat with a maximum elevation of $5 \mathrm{~m}$. The climate is subtropical with an average annual temperature of $16.7^{\circ} \mathrm{C}$ and 237 frost-free days. The average rainfall is $1239 \mathrm{~mm}$, more than $70 \%$ of which occurs from June to September. The riverine substrate is dominated by paddy soils (Agrudalfs according to the USDA Soil Taxonomic Classification) with a small quantity of fluvo-aquic soils. The study area has been traditionally associated with agricultural activities and is currently used for vegetable production. About $60 \%$ of the total field area $\left(56 \mathrm{~km}^{2}\right)$ in the island is used for the cultivation of a special medicinal vegetable, edible wild wormwood (Artemisia selengensis). In the past three decades this area has been used for the continuous cropping of vegetables and large amounts of inorganic fertilizer such as urea and composite fertilizers have been used during the last two decades.

\section{Sample collection and preparation}

A total of 222 soil samples were collected from the field. The sampling points were selected based on a regular grid of $400 \mathrm{~m} \times 400 \mathrm{~m}$ and each grid had at least one sampling point (Fig. 1). Samples were collected from the top $20 \mathrm{~cm}$ of the soil profile. Each composite sample consisted of $3-5$ sub-samples obtained using a stainless steel hand auger. All of the sampling points were recorded using a hand-held global positioning system. Soil samples were collected first from selected farms in July 2012. On the basis of the initial results additional soil samples were collected in March

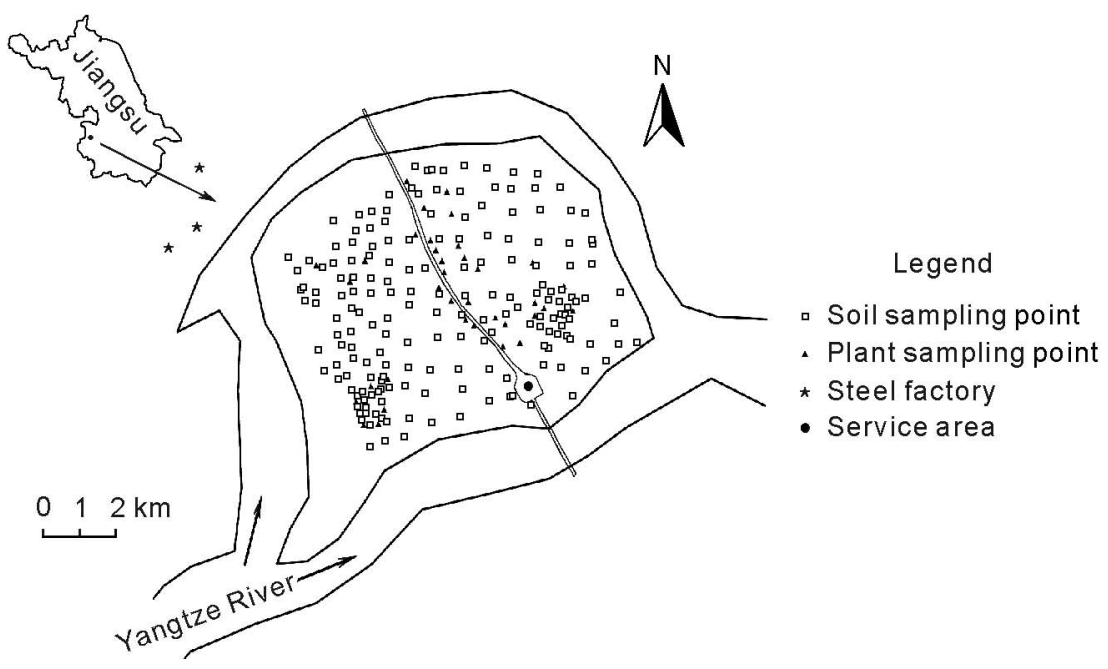

Fig. 1 Location of the study area and the sampling points in the Baguazhou Island, a suburb of Nanjing City, Jiangsu Province, East China. 
2013. All soil samples were air-dried at room temperature, stones and other debris were removed, and the samples were then passed through a 2-mm nylon sieve. Portions of soil samples (about $50 \mathrm{~g}$ ) were ground in an agate mortar and sieved through a $0.149-\mathrm{mm}$ mesh. The prepared soil samples were then stored in polyethylene bottles for analysis.

Forty vegetable samples (A. selengensis) were uprooted and gathered from polytunnel greenhouses at the end of harvest seasons and their corresponding soils were also sampled in March 2013. At each sampling plot, 3-5 soil subsamples were collected and combined for further treatment and chemical analysis. The fresh vegetable samples were placed in clean plastic bags and transported to the laboratory as soon as possible and then separated into roots, stem and leaves. The vegetable samples were washed with tap water to remove dust and extraneous matter and then with deionized water, dried in an oven for $72 \mathrm{~h}$ at $70{ }^{\circ} \mathrm{C}$ and weighed to determine their water content. The dried samples were then ground, homogenized and stored in tightly closed clean sample bottles until analysis.

\section{Chemical analysis}

Soil $\mathrm{pH}$ was determined in an aqueous extract with a soil-to-water ratio of 1:2.5 (weight/volume) using a pH meter. The total concentrations of heavy metals were determined by inductively coupled plasma-mass spectrometry (VGPQ II Agilent 7500a, Agilent, California, USA). About $0.2 \mathrm{~g}$ dried soil sample was treated

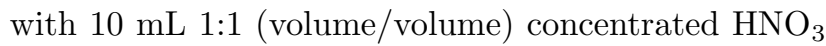
and $\mathrm{HCl}$, and placed in a Teflon vessel digester at $>120$ ${ }^{\circ} \mathrm{C}$ for $480 \mathrm{~min}$. The acid extracts were reduced to a minimum volume on hot-plates and re-diluted with $1 \%$ $\mathrm{HNO}_{3}$ for analysis. Plant materials for metal analysis were treated with $2 \mathrm{~mL} 30 \% \mathrm{H}_{2} \mathrm{O}_{2}$ and $6 \mathrm{~mL} 69 \%$ $\mathrm{HNO}_{3}$ to mineralize cellulose, and then prepared in a similar manner to the soil samples.

Quality assurance and quality control (QA/QC) for heavy metals in soil and plant samples were estimated by determining the heavy metal contents in blank and duplicate samples and certified reference materials (CRMs). The certified reference materials, including GBW07402 (chestnut colored soil), GBW07404 (calcareous soil) and GBW10014 (for plants), were obtained from the China National Center for Standard
Reference Materials. Blank and duplicate samples and the CRMs were included with every 10 samples in the analysis. The elemental recoveries and relative standard deviation for the CRMs were 92\%-108\% and < $3.6 \%$, respectively.

\section{Data analysis}

Pearson's correlation coefficient analysis and principal component analysis (PCA) were performed (Facchinelli et al., 2001; Zhang et al., 2008), using the commercial statistical software package SPSS version 17.0 for Windows, to identify the relationships among heavy metals in the soils and their possible sources. The correlation coefficient measured the strength of the inter-relationship between two heavy metals. PCA, a multivariate analytical tool, was used to reduce a set of original variables to a small number of latent factors (principal components) and analyze the relationships among the heavy metals. In addition, the normal distribution of each metal's concentration was evaluated using the Kolmogorov-Smirnov test based on the raw data.

Geostatistics provides a set of statistical tools for incorporating the spatial and temporal coordinates of observations in data processing (Saito and Goovaerts, 2000). Kriging, a geostatistical interpolation method, uses the semivariogram to quantify the spatial variability of regionalized variables and provides parameters for spatial interpolation. The maps of the spatial distribution of heavy metal concentrations were generated by kriging interpolation with the support of ArcGISGeostatistical Analyst software.

The concentration factor $(\mathrm{CF})$ is defined as the ratio of the heavy metal concentrations in roots to those in the soil. The translocation factor (TF) is the ratio of the heavy metal concentrations between one part and another part of the plant (i.e., between stem and root or between leaf and stem), which can characterize the difficulty of heavy metal translocation in the plant system (Kloke et al., 1984; Yang et al., 2008).

\section{RESULTS AND DISCUSSION}

Soil heavy metal concentrations and distribution characteristics

Soil $\mathrm{pH}$ values changed greatly from 3.87 to 8.20 
and $41.4 \%$ of the soils had $\mathrm{pH}$ above $7.5,32.9 \%$ between 6.5 and 7.5 , and only $25.7 \%$ below 6.5 . This may be partly ascribed to the parent materials, topography, soil texture, and vegetation (Helyar et al., 1990; Barton et al., 1994; Álvarez et al., 2002), and also resulted from the long-term application of chemical fertilizers (Berg, 1986; Schwab et al., 1990; Conyers et al., 1996; Wei et al., 2006; Liao et al., 2007).

Table I presents the descriptive statistics of heavy metal concentrations in the horticultural top soils and the background values of Nanjing soils. There was a distinct change in the concentrations of heavy metals among the soil samples and the concentrations of $\mathrm{Cd}$, $\mathrm{Cr}, \mathrm{Cu}, \mathrm{Ni}, \mathrm{Pb}$ and $\mathrm{Zn}$ varied from 0.101 to $0.513,43.1$ to $590,14.7$ to $85.2,19$ to $291,13.2$ to 59.7 , and 43 to $216 \mathrm{mg} \mathrm{kg}^{-1}$, respectively. The mean values of the soil heavy metal concentrations followed the descending order of $\mathrm{Cr}>\mathrm{Zn}>\mathrm{Ni}>\mathrm{Cu}>\mathrm{Pb}>\mathrm{Cd}$ and were all higher than their background values (1.65, $2.26,1.27,1.66,1.28$, and 1.49 times the corresponding background values, respectively), clearly demonstrating an anthropogenic contribution. However, except for $\mathrm{Cd}$ and $\mathrm{Ni}$, the values of $\mathrm{Cr}, \mathrm{Zn}, \mathrm{Cu}$, and $\mathrm{Zn}$ were lower than the "Grade II" limit of the Chinese Environmental Quality Standard for Agricultural Soils (GB15618-1995). The coefficients of variation varied from $18.2 \%$ for $\mathrm{Zn}$ to $111 \%$ for $\mathrm{Cr}$ and decreased in the order of $\mathrm{Cr}>\mathrm{Ni}>\mathrm{Pb}>\mathrm{Cu}>\mathrm{Cd}>\mathrm{Zn}$, indicating the significant influence of an anthropogenic contribution to soil $\mathrm{Cr}$ and $\mathrm{Ni}$ concentrations such as industrial pollution (Wu et al., 2011; Hernández-Quiroz et al., 2012) and vehicle traffic (Wu et al., 2011). Large stan- dard deviations were found for all heavy metals except Cd. This also indicated the wide variation in metal concentrations in the horticultural soils. The K-S test confirmed that the concentrations of $\mathrm{Cr}$ and $\mathrm{Ni}$ in the soils were not distributed normally, showing positively skewed data. The main contribution to heavy metal contamination in the soils of the Baguazhou Island was due to $\mathrm{Cr}$ and $\mathrm{Ni}$ and accumulation of $\mathrm{Cd}, \mathrm{Zn}$, and $\mathrm{Cu}$ concentrations in the soils was also found. In accordance with the Environmental Quality Standard for Agricultural Soils (GB15618-1995), the mean concentrations of $\mathrm{Cd}, \mathrm{Zn}, \mathrm{Cu}, \mathrm{Pb}$ and $\mathrm{Cr}$ in the top soils were lower than the maximum allowable concentrations in Chinese agricultural soils with the exception of Ni. The percentages of sampled soils exceeding the maximum allowable concentrations were $11 \%$ for $\mathrm{Cd}, 8 \%$ for $\mathrm{Cu}$, $14 \%$ for $\mathrm{Cr}$ and $41 \%$ for $\mathrm{Ni}$. This indicated that local anthropogenic activities posed a threat to food chain safety by vegetable production.

Soil $\mathrm{pH}$ is generally regarded as the most important factor affecting the solubility of heavy metals and their availability to plants (Reddy and Patrick, 1977; Zhao et al., 2010; Zeng et al., 2011). When soil pH decreased, pronounced increases of heavy metal mobility and bioavailability were observed (Badawy et al., 2002; Wang et al., 2006), thus enhancement of the uptake of heavy metals by plants and thereby the threat to human health need be concerned (Brallier et al., 1996; Oliver et al., 1996). Soil acidification can, therefore, be an effective method to promote the uptake of heavy metals by plants and then minimize the toxic effects. However, the higher mobility resulting from soil $\mathrm{pH}$

\section{TABLE I}

Basic descriptive statistics ${ }^{a)}$ of soil heavy metal concentrations in the Baguazhou Island, a suburb of Nanjing City, Jiangsu Province, East China

\begin{tabular}{|c|c|c|c|c|c|c|c|c|c|c|c|}
\hline $\begin{array}{l}\text { Heavy } \\
\text { metal }\end{array}$ & Mean & Maximum & Minimum & Median & $\mathrm{SD}$ & Skewness & Kurtosis & $\mathrm{CV}$ & $\begin{array}{l}\text { K-S } \\
\text { statistic }\end{array}$ & $\begin{array}{l}\text { Background } \\
\text { value }\end{array}$ & $\begin{array}{l}\text { EQS }^{\mathrm{b})} \\
\text { Grade II }\end{array}$ \\
\hline & & & \multicolumn{3}{|l|}{$\mathrm{mg} \mathrm{kg}^{-1}$} & & & \multicolumn{2}{|l|}{$\%$} & \multicolumn{2}{|c|}{ - $\mathrm{mg} \mathrm{kg}^{-1}$} \\
\hline $\mathrm{Cd}$ & 0.314 & 0.513 & 0.101 & 0.316 & 0.069 & -0.005 & 0.08 & 22.0 & 0.551 & 0.19 & 0.30 \\
\hline $\mathrm{Cr}$ & 133 & 590 & 43 & 103 & 156 & 7.53 & 80.0 & 111.0 & 3.94 & 59 & 200 \\
\hline $\mathrm{Cu}$ & 41.0 & 85.2 & 14.7 & 41.9 & 9.33 & 0.166 & 1.76 & 22.8 & 1.01 & 32.2 & 100 \\
\hline $\mathrm{Ni}$ & 58 & 291 & 19 & 48 & 35.7 & 3.00 & 11.8 & 61.5 & 3.74 & 35.0 & 50 \\
\hline $\mathrm{Pb}$ & 31.8 & 59.7 & 13.2 & 31.7 & 7.38 & 0.395 & 0.63 & 23.2 & 0.629 & 24.8 & 300 \\
\hline $\mathrm{Zn}$ & 114 & 216 & 43 & 116 & 20.9 & 0.124 & 2.46 & 18.2 & 1.04 & 76.8 & 250 \\
\hline
\end{tabular}

a) $\mathrm{SD}=$ standard deviation; $\mathrm{CV}=$ coefficient of variation; K-S = Kolmogorov-Smirnov test.

b) Chinese Environmental Quality Standard for Agricultural Soils (GB 15618-1995). 
TABLE II

Pearson correlation coefficients among soil heavy metal concentrations in the Baguazhou Island, a suburb of Nanjing City, Jiangsu Province, East China

\begin{tabular}{|c|c|c|c|c|c|c|}
\hline Heavy metal & $\mathrm{Cd}$ & $\mathrm{Cr}$ & $\mathrm{Cu}$ & $\mathrm{Ni}$ & $\mathrm{Pb}$ & $\mathrm{Zn}$ \\
\hline $\mathrm{Cd}$ & 1 & & & & & \\
\hline $\mathrm{Cr}$ & -0.060 & 1 & & & & \\
\hline $\mathrm{Cu}$ & $0.400 * *$ & 0.039 & 1 & & & \\
\hline $\mathrm{Ni}$ & $0.202^{* *}$ & $0.485^{* *}$ & $0.136^{*}$ & 1 & & \\
\hline $\mathrm{Pb}$ & 0.064 & 0.033 & $0.701^{* *}$ & 0.033 & 1 & \\
\hline $\mathrm{Zn}$ & $0.518^{* *}$ & 0.034 & $0.703^{* *}$ & 0.131 & $0.494^{* *}$ & 1 \\
\hline
\end{tabular}

*, **Significant at $P<0.05$ and $P<0.01$, respectively (2-tailed).

decrease could also imply heavy metal displacement to deeper soil layers and higher risk of water system contamination by leaching or runoff of heavy metals.

\section{Correlations among heavy metal concentrations}

Correlation analysis provides an effective way to reveal the relationships among multiple variables and thus contributes to an understanding of the drivers and the sources of chemical components. Heavy metals in soils usually have complicated inter-relationships. Significant positive correlation between soil heavy metals may reflect similar pollution sources (Micó et al., 2006; Li et al., 2013). The calculated Pearson correlation coefficients and their significance levels are shown in Table II. The concentration of Cd showed highly significant positive relationships with $\mathrm{Cu}(0.400), \mathrm{Ni}$ (0.202), and $\mathrm{Zn}$ (0.518). In addition, the correlations between $\mathrm{Cu}$ and $\mathrm{Pb}$ and $\mathrm{Zn}$ were significant and positive $(P<0.01)$. However, the concentrations of $\mathrm{Cr}$ and $\mathrm{Ni}$ showed weak correlations with $\mathrm{Pb}$ and $\mathrm{Zn}$, indicating that $\mathrm{Cr}$ and $\mathrm{Ni}$ may have been derived from different sources from that $\mathrm{Pb}$ or $\mathrm{Zn}$.

\section{Principal component analysis of soil heavy metals}

Principal component analysis (PCA) was adopted to identify the origin of the soil heavy metals (Table III). The eigen-values of the three extracted components were all greater than 1.0. The heavy metals were, therefore, grouped into a three-component model that accounted for $88 \%$ of the total variance in the data. The component matrix (Table IV) showed that $\mathrm{Cu}, \mathrm{Pb}$, and $\mathrm{Zn}$ were strongly associated with the first principal component (PC 1) which explained $43.3 \%$ of the total variance, while $\mathrm{Cr}$ and $\mathrm{Ni}$ were mainly distributed with the second principal component (PC 2) which ex- plained $27.6 \%$ of the total variance. The third principal component (PC 3) was correlated very strongly with Cd which had a high loading value (0.757), accounting for $17.0 \%$ of the total variance. The metals in PC 1 were mainly derived from non-anthropogenic sources, indicating local natural sources. The most important sources of $\mathrm{Cd}$ in the arable soils of suburban areas are the long-term application of fertilizers, sewage sludges, and organic manures (Zhang, 2006; Hani and Pazira, 2011). Cr and Ni in PC 2 were strongly correlated with each other and were clearly separated from the other

\section{TABLE III}

Principal component analysis for soil heavy metal concentrations in the Baguazhou Island, a suburb of Nanjing City, Jiangsu Province, East China

\begin{tabular}{llcc}
\hline $\begin{array}{l}\text { Principal } \\
\text { component }\end{array}$ & Eigen-value & $\begin{array}{l}\text { Proportion of } \\
\text { total variance }\end{array}$ & $\begin{array}{c}\text { Cumulative } \\
\text { proportion }\end{array}$ \\
\hline & & & $\%$ \\
\cline { 3 - 4 } & 2.601 & 43.342 & 43.342 \\
3 & 1.659 & 27.646 & 70.989 \\
4 & 1.020 & 17.007 & 87.996 \\
5 & 0.320 & 5.328 & 93.324 \\
6 & 0.221 & 3.684 & 97.008 \\
\hline
\end{tabular}

\section{TABLE IV}

Principal component (PC) matrices correlated with soil heavy metal concentrations in the Baguazhou Island, a suburb of Nanjing City, Jiangsu Province, East China

\begin{tabular}{lrrr}
\hline Heavy metal & PC 1 & \multicolumn{1}{c}{ PC 2 } & \multicolumn{1}{c}{ PC 3 } \\
\hline $\mathrm{Cd}$ & 0.564 & -0.150 & 0.757 \\
$\mathrm{Cr}$ & 0.357 & 0.869 & -0.168 \\
$\mathrm{Cu}$ & 0.883 & -0.385 & 0.059 \\
$\mathrm{Ni}$ & 0.399 & 0.849 & 0.171 \\
$\mathrm{~Pb}$ & 0.715 & -0.194 & -0.587 \\
$\mathrm{Zn}$ & 0.840 & -0.256 & 0.145 \\
\hline
\end{tabular}


heavy metals regarding their correlation coefficient analysis and PCA. This suggested that $\mathrm{Cr}$ and Ni were derived mainly from anthropogenic sources such as industrial activities and traffic pollution.

\section{Spatial distribution of heavy metals}

The spatial distribution of heavy metals is a useful aid to assess the possible sources of enrichment and to identify hotspots with high metal concentrations. The estimated concentration of $\mathrm{Cd}, \mathrm{Cr}, \mathrm{Cu}, \mathrm{Ni}, \mathrm{Pb}$ and $\mathrm{Zn}$ are presented in the following geochemical maps (Fig. 2), which identified several hotspots with high
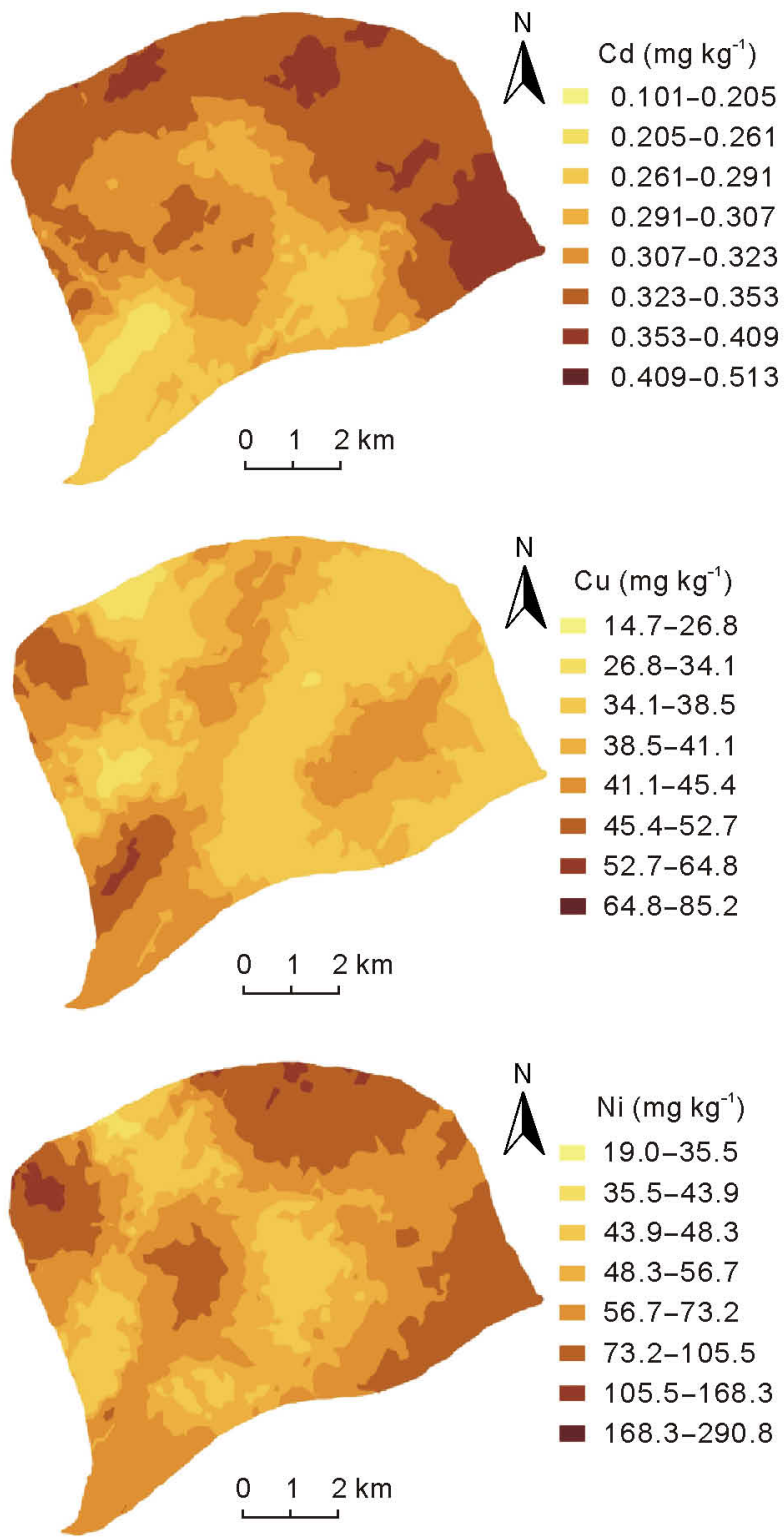

Fig. 2 Spatial distribution of soil heavy metal concentrations in the Baguazhou Island, a suburb of Nanjing City, Jiangsu Province,

East China.

metal concentrations.

The hotspots where the soils were enriched with $\mathrm{Pb}$ mostly coincided with highway gasoline stations with high vehicle exhausts. Soils act as a sink for $\mathrm{Pb}$ from atmospheric deposition. $\mathrm{Pb}$ aerosols can be transported over long distances in the atmosphere, resulting in high concentration of $\mathrm{Pb}$ in the soils around the pollution sources. However, the transport of heavy metals from urban to surrounding areas is limited to a circumference of approximately $1 \mathrm{~km}$, with $\mathrm{Pb}$ concentrations showing a declining trend with increasing distance from the pollution source (Biasioli et al., 2006).
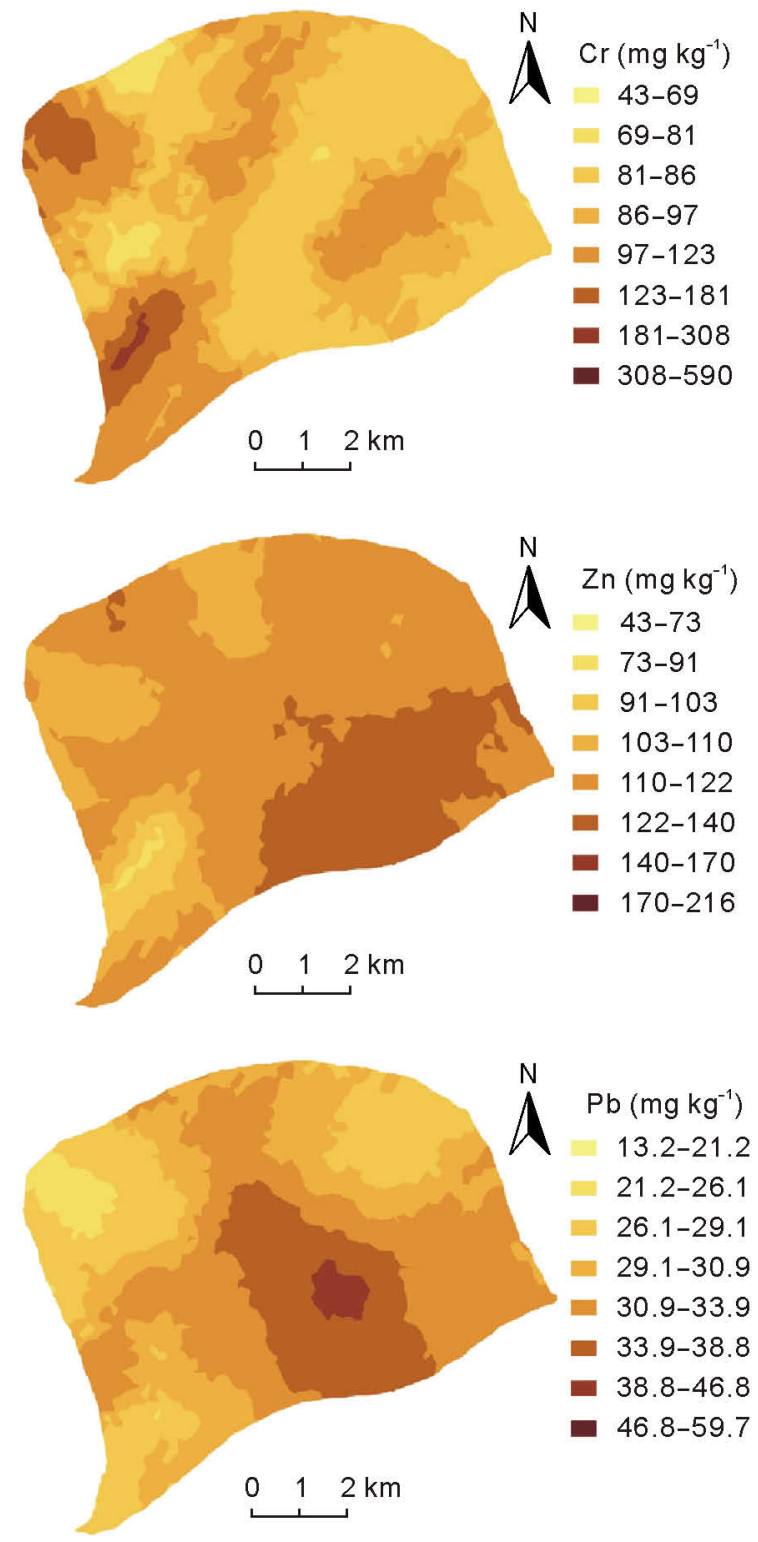
The higher Cd concentration tended to occur in the southeast and northeast and this may be associated with agricultural activities such as application of pesticides, phosphorus fertilizers and plastic film (for plastic greenhouses or mulching) containing Cd (Kachenko and Singh, 2006; Montagne et al., 2007).

The concentrations of soil $\mathrm{Cu}$ and $\mathrm{Zn}$ were higher in the southeast of the study area and their spatial distribution showed a good correlation with the distribution of riverine and marine deposits, indicating the influence of soil parent materials.

Another pollution hotspot was evident at the northwest corner of the study area. This area was most polluted with $\mathrm{Cr}$ and $\mathrm{Ni}$ and second most polluted with Cd. Many heavy industries such as steelworks and chemical industries are located nearby across the river and this pollution hotspot may, therefore, reflect industrial inputs.

\section{Distribution of heavy metals in plant parts}

The concentrations of 6 heavy metals in the $A$. selengensis samples (Fig. 3) were all below the Chinese maximum allowable concentrations in food (GB27622012: $\mathrm{Pb} 0.1 \mathrm{mg} \mathrm{kg}^{-1}$, Cd $0.1 \mathrm{mg} \mathrm{kg}^{-1}$, Cr $0.5 \mathrm{mg} \mathrm{kg}^{-1}$, and Ni $1.0 \mathrm{mg} \mathrm{kg}^{-1}$; GB15199-94: Cu $10 \mathrm{mg} \mathrm{kg}^{-1}$; and GB13106-91: Zn $20 \mathrm{mg} \mathrm{kg}^{-1}$ ). The concentrations of $\mathrm{Cd}, \mathrm{Pb}$, and $\mathrm{Zn}$ in different plant parts showed the order of leaves $>$ stems $>$ roots. The leaves were the main site of heavy metal accumulation. However, $\mathrm{Cu}$ concentrations followed the sequence of stems $>$ leaves $>$ roots. The tissue concentrations of $\mathrm{Ni}$ showed the order of stems $>$ roots $>$ leaves and $\mathrm{Cr}$ had a similar trend. The relatively low concentrations of $\mathrm{Cd}, \mathrm{Pb}$, and $\mathrm{Zn}$ in the roots and stems may be due to the transport function of these plant parts. It can also be indicated that $A$. selengensis might absorb heavy metals from the air or by atmospheric deposition through its leaves (Luo et al., 2011), resulting in higher concentrations of heavy metals in the leaves than in the roots and stems. In addition, the differences in the accumulation and distribution of heavy metals among the different plant parts may be related to the differences in the characteristics of heavy metals, their toxicity, and their concentrations in the soils.

The concentration factors $(\mathrm{CF})$ and translocation factors (TF) were calculated to study the accumula- tion and transport characteristics of heavy metals in different plant parts (Kloke et al., 1984; Yang et al., 2008). In general, heavy metals showed distinct differences in their concentration factors. The concentration factor of $\mathrm{Cd}$ was the highest and the CFs of $\mathrm{Cd}$ in the leaves, stems and roots were 1.80, 1.57 and 1.08, respectively, indicating that the plants had very strong $\mathrm{Cd}$ enrichment capacity. The plant $\mathrm{CF}$ of $\mathrm{Cu}$ was the second highest, with values in the leaves, stems and roots of $0.781,0.783$ and 0.604 , respectively. Generally, $\mathrm{Cu}$ and $\mathrm{Zn}$ are taken up as micronutrients essential for plant growth. However, $\mathrm{Pb}$ and $\mathrm{Cr}$ are nonessential and their root uptake was limited as their diminished transfer capacities from roots to stems and leaves (0.003 and 0.014, respectively).

Table $\mathrm{V}$ shows the TFs of heavy metals in the plants and the values followed the order of $\mathrm{Pb}>\mathrm{Cd}$ $>\mathrm{Zn}>\mathrm{Cu}>\mathrm{Ni}>\mathrm{Cr}$. This agrees with the results of some previous studies with the sole exception of Pb (Khan et al., 2008; Zhuang et al., 2009; Cao et al., 2010). As a result, $\mathrm{Pb}$ may have been readily transported from roots to stems but $\mathrm{Ni}$ and $\mathrm{Cr}$ were relatively immobile. From stems to leaves the $\mathrm{TF}$ of $\mathrm{Pb}$ was the highest at 2.05 and that of $\mathrm{Ni}$ was the lowest at 0.926 . The translocation ability of each plant part indicates some resistance to related heavy metals. The higher the translocation ability for heavy metals of a tissue is, the lower the resistance and the lower its retention capability are (Yang et al., 2008).

\section{CONCLUSIONS}

Anthropogenic activities affected the heavy metal concentrations in the soils and vegetables in the Baguazhou Island, but most of the soil samples were still safe for vegetable production according to the Chinese Environmental Quality Standard for Agricultural Soils. Soil $\mathrm{Cu}$ and $\mathrm{Zn}$ were derived mainly from the soil parent materials. Local contamination from agricultural practices, particularly the application of fertilizers and manures, was the primary source of $\mathrm{Cd}$ contamination in the soils, and atmospheric deposition played an important role in soil $\mathrm{Pb}$ accumulation. $\mathrm{Cr}$ and $\mathrm{Ni}$ had anthropogenic origins and their spatial distributions showed a point source contamination, suggesting significant anthropogenic inputs of $\mathrm{Cr}$ and $\mathrm{Ni}$ in the study area. The locally important speciality vegetable 


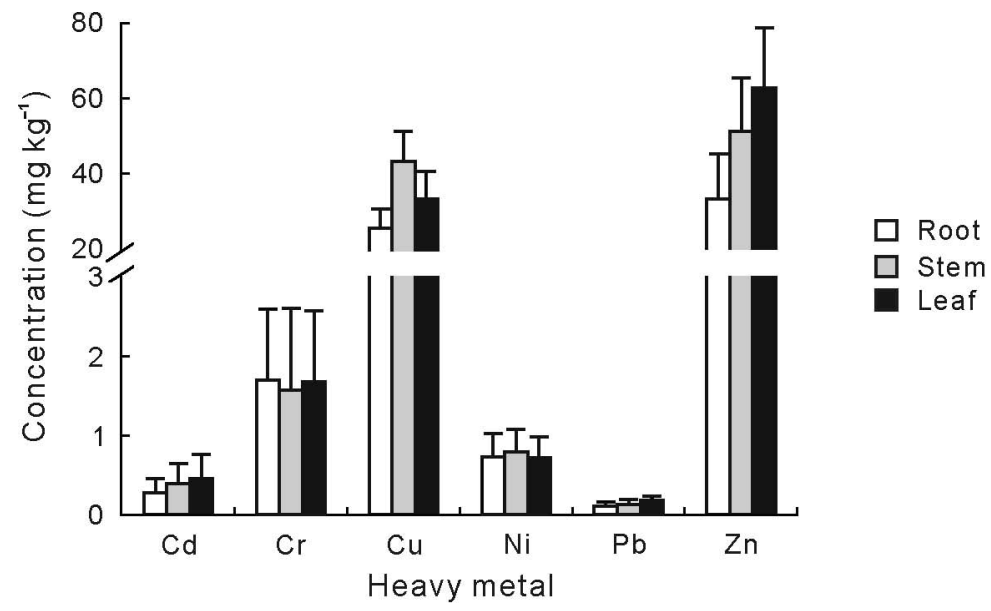

Fig. 3 Concentrations of heavy metals (dry weight basis) in roots, stems, and leaves of Artemisia selengensis, a locally important speciality vegetable in the Baguazhou Island, a suburb of Nanjing City, Jiangsu Province, East China.

\section{TABLE V}

Translocation factors of heavy metals in Artemisia selengensis, a locally important speciality vegetable in the Baguazhou Island, a suburb of Nanjing City, Jiangsu Province, East China

\begin{tabular}{lllllll}
\hline Translocation factor & $\mathrm{Cd}$ & $\mathrm{Cr}$ & $\mathrm{Cu}$ & $\mathrm{Ni}$ & $\mathrm{Pb}$ & $\mathrm{Zn}$ \\
\hline Between stem and root & 1.663 & 1.095 & 1.341 & 1.177 & 1.830 & 1.657 \\
Between leaf and stem & 1.296 & 1.236 & 1.000 & 0.926 & 2.045 & 1.239 \\
\hline
\end{tabular}

A. selengensis had the highest $\mathrm{CF}$ for $\mathrm{Cd}$ and the second highest for $\mathrm{Cu}$. Plant uptake capacity for $\mathrm{Pb}$ and $\mathrm{Cr}$ was relatively low. $\mathrm{Cd}$ showed the highest $\mathrm{CF}$ and $\mathrm{TF}$ in A. selengensis, indicating that this plant species had a high capacity for Cd uptake. These results may provide a basis for the effective targeting of policies to reduce metal inputs and to protect soils and consumers from long-term heavy metal toxicity.

\section{ACKNOWLEDGEMENT}

This study was supported by the National High Technology Research and Development Program (863 Program) of China (No. 2012AA101402-2).

\section{REFERENCES}

Álvarez E, Monterroso C, Fernández Marcos M L. 2002. Aluminium fractionation in Galician (NW Spain) forest soils as related to vegetation and parent material. Forest Ecol Manag. 166: 193-206.

Badawy S H, Helal M I D, Chaudri A M, Lawlor K, McGrath S P. 2002. Soil solid-phase controls lead activity in soil solution. J Environ Qual. 31: 162-167.

Barton D, Hope D, Billett M F, Cresser M S. 1994. Sulfate adsorption capacity and $\mathrm{pH}$ of upland podzolic soils in Scotland: effects of parent material, texture and precipitation chemistry. Appl Geochem. 9: 127-139.

Berg W A. 1986. Effect of 20 years of low N rate pasture fertilization on soil acidity. J Range Manage. 39: 122-124.

Biasioli M, Barberis R, Ajmone-Marsan F. 2006. The influence of a large city on some soil properties and metals content. Sci Total Environ. 356: 154-164.

Bilos C, Colombo J C, Skorupka C N, Rodriguez Presa M J. 2001. Sources, distribution and variability of airborne trace metals in La Plata City area, Argentina. Environ Pollut. 111: $149-158$.

Brallier S, Harrison R B, Henry C L, Dongsen X. 1996. Liming effects on availability of $\mathrm{Cd}, \mathrm{Cu}, \mathrm{Ni}$ and $\mathrm{Zn}$ in a soil amended with sewage sludge 16 years previously. Water Air Soil Poll. 86: 195-206.

Cai L M, Huang L C, Zhou Y Z, Xu Z C, Peng X C, Yao L A, Zhou Y, Peng P A. 2010. Heavy metal concentrations of agricultural soils and vegetables from Dongguan, Guangdong. J Geogr Sci. 20: 121-134.

Cai L M, Xu Z C, Ren M Z, Guo Q W, Hu X B, Hu G C, Wan H F, Peng P G. 2012. Source identification of eight hazardous heavy metals in agricultural soils of Huizhou, Guangdong Province, China. Ecotox Environ Safe. 78: 2-8.

Cao H B, Chen J J, Zhang J, Zhang H, Qiao L, Men Y. 2010. Heavy metals in rice and garden vegetables and their potential health risks to inhabitants in the vicinity of an industrial zone in Jiangsu, China. J Environ Sci. 22: 1792-1799.

Cheng S P. 2003. Heavy metal pollution in China: Origin, pattern and control. Environ Sci Pollut R. 10: 192-198.

Conyers M K, Heenan D P, Poile G J, Cullis B R, Helyar K R. 1996. Influence of dryland agricultural management prac- 
tices on the acidification of a soil profile. Soil Till Res. 37: $127-141$

Facchinelli A, Sacchi E, Mallen L. 2001. Multivariate statistical and GIS-based approach to identify heavy metal sources in soils. Environ Pollut. 114: 313-324.

Hani A, Pazira E. 2011. Heavy metals assessment and identification of their sources in agricultural soils of Southern Tehran, Iran. Environ Monit Assess. 176: 677-691.

Helyar K R, Cregan P D, Godyn D L. 1990. Soil acidity in New South Wales - Current $\mathrm{pH}$ values and estimates of acidification rates. Aust J Soil Res. 28: 523-537.

Hernández-Quiroz M, Herre A, Cram S, Ponce de León C, Siebe C. 2012. Pedogenic, lithogenic- or anthropogenic origin of $\mathrm{Cr}$ $\mathrm{Ni}$ and $\mathrm{V}$ in soils near a petrochemical facility in Southeast Mexico. Catena. 93: 49-57.

Hlavay J, Polyák K, Weisz M. 2001. Monitoring of the natural environment by chemical speciation of elements in aerosol and sediment samples. J Environ Monitor. 3: 74-80.

Huang S S, Liao Q L, Hua M, Wu X M, Bi K S, Yan C Y, Chen B, Zhang X Y. 2007. Survey of heavy metal pollution and assessment of agricultural soil in Yangzhong district, Jiangsu Province, China. Chemosphere. 67: 2148-2155.

Kachenko A G, Singh B. 2006. Heavy metals contamination in vegetables grown in urban and metal smelter contaminated sites in Australia. Water Air Soil Poll. 169: 101-123.

Khan S, Cao Q, Zheng Y M, Huang Y Z, Zhu Y G. 2008. Health risks of heavy metals in contaminated soils and food crops irrigated with wastewater in Beijing, China. Environ Pollut. 152: $686-692$.

Kloke A, Sauerbeck D R, Vetter H. 1984. The contamination of plants and soils with heavy metals and the transport of metals in terrestrial food chains. In Nriagu J O (ed.) Changing Metal Cycles and Human Health. Report of the Dahlem Workshop on Changing Metal Cycles and Human Health, Berlin. March 20-25, 1983. Springer, Berlin, Heidelberg. pp. 113-141

Koch M, Rotard W. 2001. On the contribution of background sources to the heavy metal content of municipal sewage sludge. Water Sci Technol. 43: 67-74.

Lee C S L, Li X D, Shi W Z, Cheung S C N, Thornton I. 2006. Metal contamination in urban, suburban, and country park soils of Hong Kong: a study based on GIS and multivariate statistics. Sci Total Environ. 356: 45-61.

Li X D, Lee S L, Wong S C, Shi W Z, Thornton I. 2004. The study of metal contamination in urban soils of Hong Kong using a GIS-based approach. Environ Pollut. 129: 113-124.

Li X Y, Liu L J, Wang Y G, Luo G P, Chen X, Yang X L, Hall M H P, Guo R C, Wang H J, Cui J H, He X Y. 2013. Heavy metal contamination of urban soil in an old industrial city (Shenyang) in Northeast China. Geoderma. 192: 50-58.

Liao Q L, Evans L J, Gu X, Fan D F, Jin Y, Wang H. 2007. A regional geochemical survey of soils in Jiangsu Province, China: preliminary assessment of soil fertility and soil contamination. Geoderma. 142: 18-28.

Luo C L, Liu C P, Wang Y, Liu X A, Li F B, Zhang G, Li X D. 2011. Heavy metal contamination in soils and vegetables near an e-waste processing site, south China. J Hazard Mater. 186: 481-490.
Micó C, Recatalá L, Peris M, Sánchez J. 2006. Assessing heavy metal sources in agricultural soils of an European Mediterranean area by multivariate analysis. Chemosphere. 65: $863-$ 872.

Montagne D, Cornu S, Bourennane H, Baize D, Ratié C, King D. 2007. Effect of agricultural practices on trace-element distribution in soil. Commun Soil Sci Plan. 38: 473-491.

Oliver D P, Tiller K G, Conyers M K, Slattery W J, Alston A M, Merry R H. 1996. Effectiveness of liming to minimise uptake of cadmium by wheat and barley grain grown in the field. Aust J Agr Res. 47: 1181-1193.

Reddy C N, Patrick W H. 1977. Effect of redox potential and $\mathrm{pH}$ on the uptake of cadmium and lead by rice plants. $J$ Environ Qual. 6: 259-262.

Saito H, Goovaerts P. 2000. Geostatistical interpolation of positively skewed and censored data in a dioxin-contaminated site. Environ Sci Technol. 34: 4228-4235.

Schwab A P, Owensby C E, Kulyingyong S. 1990. Changes in soil chemical properties due to 40 years of fertilization. Soil Sci. 149: 35-43.

Sridhara Chary N, Kamala C T, Samuel Suman Raj D. 2008. Assessing risk of heavy metals from consuming food grown on sewage irrigated soils and food chain transfer. Ecotox Environ Safe. 69: 513-524.

Tan M Z, Xu F M, Chen J, Zhang X L, Chen J Z. 2006. Spatial prediction of heavy metal pollution for soils in peri-urban Beijing, China based on fuzzy set theory. Pedosphere. 16 545-554.

Wang A S, Scott Angle J, Chaney R L, Delorme T A, Reeves R D. 2006. Soil $\mathrm{pH}$ effects on uptake of $\mathrm{Cd}$ and $\mathrm{Zn}$ by Thlaspi caerulescens. Plant Soil. 281: 325-337.

Wang C, Yang Z F, Yuan X Y, Browne P, Chen L X, Ji J F. 2013 The influences of soil properties on $\mathrm{Cu}$ and $\mathrm{Zn}$ availability in soil and their transfer to wheat (Triticum aestivum L.) in the Yangtze River delta region, China. Geoderma. 193-194 131-139.

Wei X R, Hao M D, Shao M G, Gale W J. 2006. Changes in soil properties and the availability of soil micronutrients after 18 years of cropping and fertilization. Soil Till Res. $\mathbf{9 1}$ 120-130.

Wilson B, Pyatt F B. 2007. Heavy metal dispersion, persistance, and bioccumulation around an ancient copper mine situated in Anglesey, UK. Ecotox Environ safe. 66: 224-231.

Wu S H, Zhou S L, Li X G. 2011. Determining the anthropogenic contribution of heavy metal accumulations around a typical industrial town: Xushe, China. J Geochem Explor. 110: 92-97.

Yang H J, Shen Z M, Zhu S H, Wang W H. 2008. Heavy metals in wetland plants and soil of Lake Taihu, China. Environ Toxicol Chem. 27: 38-42.

Zeng F R, Ali S, Zhang H T, Ouyang Y B, Qiu B Y, Wu F B, Zhang G P. 2011. The influence of $\mathrm{pH}$ and organic matter content in paddy soil on heavy metal availability and their uptake by rice plants. Environ Pollut. 159: 84-91.

Zhang C B, Wu L H, Luo Y M, Zhang H B, Christie P. 2008. Identifying sources of soil inorganic pollutants on a regional scale using a multivariate statistical approach: Role of pollutant migration and soil physicochemical properties. Environ 
Pollut. 151: 470-476.

Zhang C S. 2006. Using multivariate analyses and GIS to identify pollutants and their spatial patterns in urban soils in Galway, Ireland. Environ Pollut. 142: 501-511.

Zhao K L, Liu X M, Xu J M, Selim H M. 2010. Heavy metal contaminations in a soil-rice system: Identification of spatial dependence in relation to soil properties of paddy fields. $J$ Hazard Mater. 181: 778-787.

Zhuang P, McBride M B, Xia H P, Li N Y, Li Z A. 2009. Health risk from heavy metals via consumption of food crops in the vicinity of Dabaoshan mine, South China. Sci Total Environ. 407: 1551-1561. 